\title{
STUDI PENGERINGAN IKAN LAYANG (Decapterus sp) ASIN DENGAN PENGGUNAAN ALAT PENGERING SURYA
}

\author{
Elieser Imbir ${ }^{1}$, Hens Onibala ${ }^{2}$, Jenki Pongoh ${ }^{2}$ \\ 1) Mahasiswa pada Program Studi Teknologi Hasil Perikanan FPIK Unsrat Manado \\ 2) Staf pengajar pada Program Studi Teknologi Hasil Perikanan FPIK Unsrat Manado
}

\begin{abstract}
ABSTRAK
Proses pembusukan ikan dapat disebabkan oleh aktivitas enzim dalam tubuh ikan, aktivitas mikroorganisme, atau proses oksidasi lemak oleh oksigen dari udara. Oleh karena itu pentingnya tindakan proses pengolahan dan pengawetan ikan. Pengawetan ikan secara tradisional maupun semi modern berupa pengeringan bertujuan untuk mengurangi kadar air dalam tubuh ikan, sehingga tidak memberikan kesempatan bagi bakteri untuk berkembang biak. Berkurangnya kadar air juga akan terjadi selama proses pengeringan, sehingga makin memperpanjang daya awet ikan asin. Penelitian ini bertujuan untuk mengetahui perbedaan ikan layang yang dikeringkan dengan cara pengeringan yang berbeda yaitu yang digantung dan yang direbahkan. Metode yang digunakan dalam penelitian ini merupakan metode eksperimen. Metode eksperimen merupakan bagian dari metode kuantitatif yang dilaksanakan di Laboratorium. Adapun perlakuan yang dilakukan yaitu Rak 1, 2, 3 dan 4 dengan posisi ikan layang di gantung dan Rak 1, 2, 3 dan 4 dengan posisi ikan di rebahkan. Di ketahui bahwa Ikan layang asin yang dikeringkan selama 8 jam dalam alat pengering surya dengan perlakuan pada rak bagian atas dengan posisi ikan di gantung memiliki nilai rata- rata kadar air terendah, sedangkan nilai rata -rata organoleptik secara umum pada rak bagian terngah memiliki nilai terendah. Perubahan suhu dalam alat pengering sangat ditentukan oleh suhu lingkungan di luar dalam hal ini pengaruh sinar matahari yang menembus alat pengering surya yang digunakan. Suhu tertinggi pada siang hari yaitu pada jam 14:00 Wita atau jam 2 sore hari.
\end{abstract}

Kata kunci: Layang (Decapterus sp), ikan asin, pengeringan matahari.

\section{PENDAHULUAN}

Ikan merupakan salah satu sumber protein hewani yang banyak dikonsumsi masyarakat, mudah didapat, dan harganya murah. Namun hasil perikanan merupakan komoditas yang mudah mengalami proses kemunduran mutu dan pembusukan, di mana hal ini terjadi setelah ikan di tangkap. Dengan demikian perlu penanganan yang cepat, tepat dan benar untuk menjaga kualitasnya sebelum dipasarkan dan sampai ke tangan konsumen, maka perlu adanya pengawetan untuk memperpanjang daya awet.

Proses pengolahan dan pengawetan ikan merupakan salah satu bagian penting dari mata rantai industri perikanan. Tanpa adanya kedua proses tersebut, peningkatan produksi ikan yang telah dicapai selama ini akan sia-sia, karena tidak semua produk perikanan dapat dimanfaatkan oleh kosumen dalam keadaan baik. Pengawetan ikan secara tradisional bertujuan untuk mengurangi kadar air dalam tubuh ikan, sehingga tidak memberikan kesempatan bagi bakteri untuk berkembang biak. Untuk mendapatkan hasil awetan yang bermutu tinggi diperlukan perlakuan yang baik selama proses pengawetan seperti : menjaga kebersihan bahan dan alat yang digunakan, menggunakan ikan yang masih segar serta garam yang bersih. Ada bermacam-macam pengawetan ikan, antara lain dengan cara : penggaraman, pengeringan, pemindangan, peresapan, peragian, dan pendinginan ikan (Margono dkk, 2000).

Salah satu produk pengawetan yang banyak terdapat di Indonesia adalah ikan asin. Dalam skala nasional, ikan asin merupakan salah satu produk perikanan yang mempunyai kedudukan penting, hal ini dapat dilihat bahwa hampir $65 \%$ produk perikanan masih diolah dan diawetkan dengan cara penggaraman (Afrianto dan Liviawaty, 1989). Pemerintah Indonesia telah menetapkan ikan asin sebagai salah satu dari sembilan bahan pokok masyarakat. Hal ini menunjukan bahwa ikan asin tidak hanya digemari oleh masyarakat ekonomi kelas bawah, tetapi juga kelas menengah dan atas. Daya tarik ikan asin ini terutama terletak pada citarasa, aroma dan teksturnya yang khas (Astawan, 1997).

Apabila ikan asin masih tetap dipertahankan sebagai bahan makanan pokok, 
maka pilihan teknologi haruslah pada industri pengeringan dengan mekanisasi penuh. Di daerah tropis, bila pengeringan dilakukan hanya pada sinar matahari, besar kemungkinan proses pembusukan akan terjadi. Untuk mencegah hal tersebut, maka sebaiknya dilakukan pengeringan dengan pengeringan buatan (pengering surya) sehinggga proses pengeringan dapat dipercepat (Berhimpon, et al. 1990).

Sehubungan dengan hal-hal tersebut, maka perlu untuk melakukan penelitian studi lama pengeringan ikan Layang (Decapterus sp) asin dihubungkan dengan kadar air dan nilai organoleptik

Penelitian ini bertujuan untuk mengetahui perbedaan ikan layang yang dikeringkan dengan cara pengeringan yang berbeda yaitu yang digantung dan yang direbahkan.

\section{METODOLOGI PENELITIAN}

Metode yang digunakan dalam penelitian ini merupakan metode eksperimen. Metode eksperimen merupakan bagian dari metode kuantitatif yang dilaksanakan di Laboratorium (Fatabura, 2012).

\section{Tempat dan Waktu Penelitian}

Pelaksanaan penelitian bertempat di Laboratorium Penanganan dan Pengolahan Hasil Perikanan, Fakultas Perikanan dan Ilmu Kelautan, Universitas Sam Ratulangi Manado. Waktu penelitian telah dilaksanakan sejak akhir bulan Septemnber 2014 sampai pertengahan Desember 2014.

\section{Bahan Baku dan Alat}

Baku yang digunakan dalam penelitian ini adalah ikan Layang (Decapterus sp)dengan ukuran panjang berkisar antara $15-18 \mathrm{~cm}$ dan berat per ekor 40-50 gram. Jumlah ikan yang digunakan 18 ekor. Untuk bahan pengawet digunakan garam dapur $(\mathrm{NaCl})$ yang halus dan es. Peralatan yang digunakan untuk penelitian ini yaitu: pisau, talenan, wadah plastik, timbangan, mistar, cool box, thermometer dan alat pengering buatan (cabinet dryer). Sedangkan alat untuk pengujian organoleptik antara lain, piring, score sheet, dan tissue, untuk pengujian kadar air dibutuhkan alat: cawan porselin, oven, desikator dan timbangan analitik.

\section{Tata Laksana Penelitian}

- Bahan ikan yang dilakukan penelitian diambil dari Pasar 66 Bahu Kecamatan Malalayang, kemudian dibawa ke Laboratorium Penanganan dan Pengolahan Hasil Perikanan FPIK Unsrat dengan cara meletakkan ikan dalam cool box yang diberi hancuran es.

- Setelah tiba di Laboratorium, ikan tersebut kemudian dicuci dengan air bersih dan dibelah 2 sepanjang garis punggung sampai pada bagian perut (tapi jangan sampai terpisah), hal ini bertujuan agar daging ikan tidak terlalu tebal.

- Kemudian isi perut dan insang dikeluarkan, setelah itu ikan dicuci bersih agar semua kotoran yang masih melekat, terutama bagian rongga perut dan sisa-sisa pembuluh darah serta selaput yang ada dapat dibersihkan.

- Setelah itu ikan tersebut direndam dalam larutan air garam dengan konsentrasi $15 \%$ yang arti nya 15 gram garam yang di rendam dalam100 liter air dengan waktu perendaman 30 menit. Ikan kemudian diangkat dan ditiriskan sampai sisa-sisa air hasil rendaman sudah tidak meleleh lagi.

- Selanjutnya ikan dimasukkan kedalam lemari atau alat pengering surya untuk dilakukan pengeringan. Suhu pengeringan pada siang hari dan berkisar $21-53^{\circ} \mathrm{C}$ dengan waktu perlakuan selama 8 jam.

- Setelah pengeringan, ikan tersebut diangkat.

- Kemudian dilakukan pengujian Uji Kadar Air dan Organoleptik.

\section{HASIL DAN PEMBAHASAN}

\section{Nilai Kadar Air (\%)}

Hubungan kadar air ikan Layang asin dengan perlakuan posisi ikan yang berbeda saat dikeringkan. dapat di lihat pada Gambar 3.Hubungan Nilai kadar air ikan Layang asin dengan perlakuan posisi ikan berbeda saat dikeringkan. Untuk lebih jelas lihat pada Gambar 1.

Menurut Harikedua, $d k k$ (1991), pengeringan ikan dapat mengeluarkan atau menghilangkan sebagian air dari suatu bahan dengan cara menguapkan air dalam bahan tersebut dengan menggunakan energi panas. Lebih lanjut menurut Moeljanto (1982) pengeringan didasari atas terjadinya penguapan air karena adanya perbedaan kandungan uap air antara udara dengan produk yang dikeringkan. 
Kandungan uap air udara lebih rendah dari kandungan uap air produk sehingga dapat terjadi penguapan. Makin besar perbedaan tersebut, makin banyak kandungan uap air produk yang dikeringkan dapat menguap.

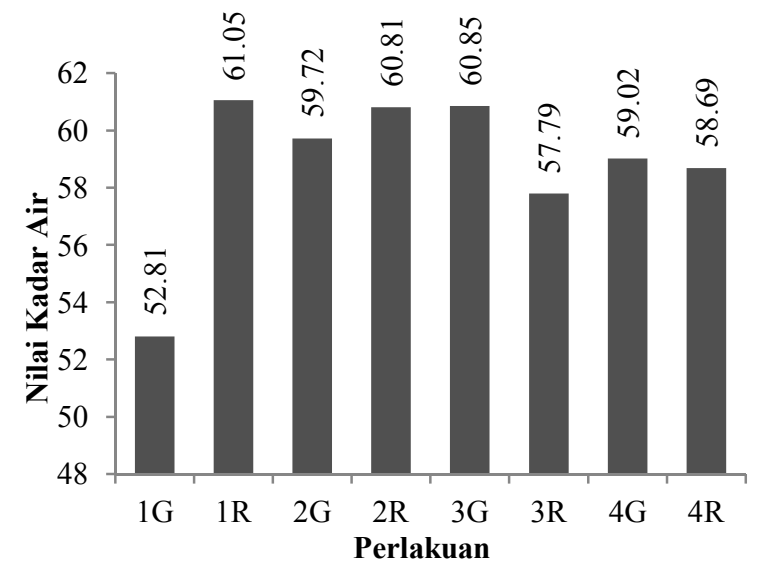

Gambar 1. Hubungan Nilai kadar air ikan layang (Dekapterus sp) asin dengan perlakuan posisi ikan yang berbeda saat dikeringkan

Menurut Badan Standar Nasional (1992), kadar air ikan asin berdasarkan Standar Nasional Indonesia adalah $40 \%$. Dengan demikian produk ikan layang asin yang mendapat perlakuan pada masing-masing rak pada alat pengeringan surya dengan lama pengeringan $8 \mathrm{jam}$, berada pada kisaran mutu kadar air yang lebih tinggi. Menurut Soeseno (1985), kadar air yang baik untuk semua jenis ikan asin yaitu $30 \%$. Oleh karena itu untuk mencapai nilai kadar air yang berkualitas baik sesuai Standar Nasional Indonesia sekitar $40 \%$ sehingga perlu dilakukan tambahan waktu pengeringan.

\section{Uji Organoleptik \\ Kenampakan}

Diketahui nilai rata-rata organoleptik kenampakan yang tertinggi adalah 8.73 yaitu pada perlakuan untuk rak bagian atas dengan posisi ikan di gantung pada saat pengeringan dalam lemari atau alat pengering surya, sedangkan nilai organoleptik kenampakan terendah adalah 5.80 untuk bagian rak tengah dengan posisi ikan digantung pada saat pengering dalamn lemari atau alat pengering surya.

Untuk lebih jelasnya hubungan nilai rata-rata organoleptik kenampakan ikan Layang asin dengan perlakuan posisi ikan yang berbeda saat dikeringkan dapat dilihat pada Gambar 2.

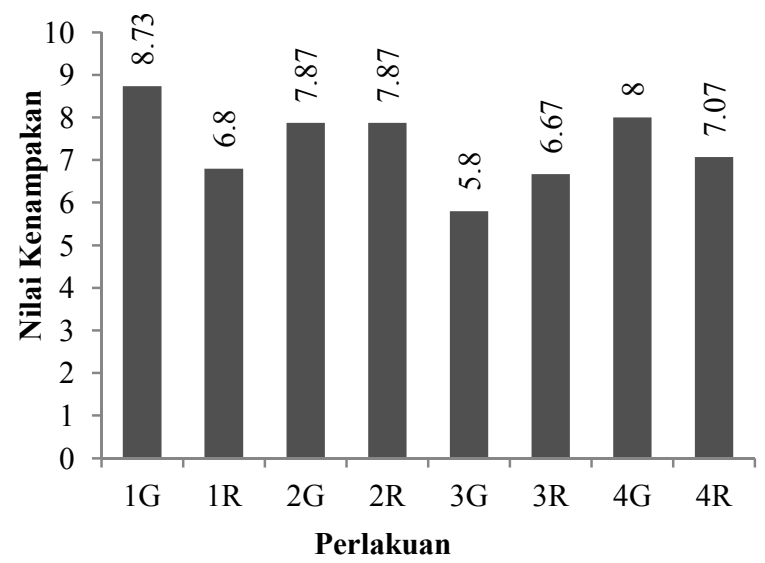

Gambar 2. Hubungan

Kenampakan

(Decapterus sp) asin perlakuan posisi ikan yang berbeda saat dikeringkan.

Berdasarkan Gambar 2 dapat dilihat bahwa pada rak bagian atas uji organoeptik kenampakanl ikan layang asin memiliki nilai rata-rata tertinggi dengan nilai rata-rata 80,73. Sedangkan pada rak bagian tengah uji organoleptik kenampakan ikan layang asin memiliki nilai rata-rata terendah dengan nilai rata-rata 5,80. Hal ini disebabkan karena bagian tengah dari alat pengering pada saat pengeringan pengaruh suhu semakin berkurang di bandingkan dengan bagian atas dan bagian bawa. Bagian atas dari alat pengering surya merupakan bagian yang terlebih dahulu terkena pengaruh sinar matahari dan bagian bawa dari rak alat pengering surya di sebabkan adanya pantulan dari bahan dasar plat seng yang digunakan

\section{Bau}

Diketahui nilai rata-rata organoleptik bau yang tertinggi adalah 7.78 yaitu pada perlakuan pada rak bagian atas dari alat pengering surya dengan posisi ikan digantung pada saat proses pengeringan berlangsung dengan lama pengeringan 8 jam, sedangkan nilai rata rata organoleptik bau terendah adalah 6.60 dengan perlakuan pada rak bagian tengah dari alat pengering surya dengan poisisi ikan di rebahkan pada saat proses pengering berlangsung selama pengeringan 8 jam.

Untuk jelasnya hubungan nilai organoleptik bau ikan Layang asin dengan perlakuan posisi ikan yang berbeda saat dikeringkan dapat dilihat pada Gambar 3. 


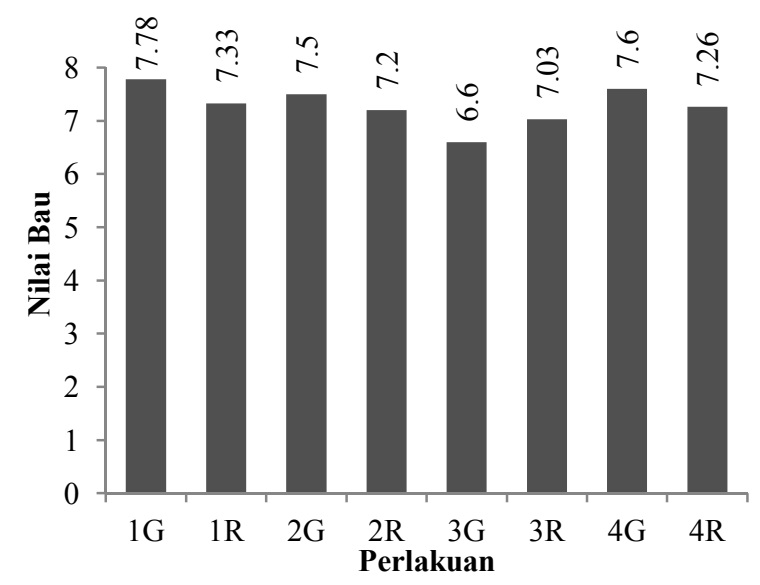

Gambar 3. Hubungan Nilai Organoleptik Bau ikan Layang (Decapterus sp) asin dengan perlakuan posisi ikan yang berbeda saat dikeringkan.

Berdasarkan Gambar 5 dapat dilihat bahwa pada rak bagian tengah nilai rata- rata organoleptik bau ikan layang asin memiliki nilai yang rendah. Hal ini disebabkan karena bagian tengah dari alat pengering pada saat pengeringan pengaruh suhu semakin berkurang di bandingkan dengan bagian atas dan bagian bawa. Diketahui pula bahwa nilai rata-rata prganoleptik bau ikan layang asin pada rak bagian atas maupun rak bagian bawa memiliki nilai tertinggi dengan posisi ikan di gantung selama proses pengeringan berlangsung dalam alat pengering surya. Tingginya nilai bau disebabkan oleh semakin kurangnya kadar air dalam daging ikan akibat pengeringan, sehingga bau asli daripada daging ikan (bau anyir) menghilang dan bau yang ditimbulkan akibat garam lebih terasa. Seperti halnya pada uji kenampakan, berdasarkan hasil di atas dapat dinyatakan bahwa semakin rendah jumlah kadar air dari produk ikan layang asin maka nilai organoleptik bau produk tersebut semakin baik. Berdasarkan Standar Nasional Indonesia (1992) nilai organoleptik yang baik adalah 6.5. Dengan demikian produk yang mendapat perlakuan pada bagian rak tengah dengan posisi ikan di gantung memilki nilai di bawa standar. Walaupun secara umum ikan layang asin yang diberi perlakuan pada masing-masing rak dengan posisi ikan di gantung maupun di rebahkan memiliki nilai berada pada kisaran mutu yang baik

Rasa

Diketahui rata-rata organoleptik rasa yang tertinggi adalah 7.73 yaitu perlakuan pada rak bagian bawa dengan posisi ikan di rebahkan dalam alat pengering surya selama 8 jam, sedangkan nilai organoleptik rasa terendah adalah 5.67 dengan perlakuan pada rak bagian tengah dengan posisi ikan di rebahkan dalam alat pengering surya selama 8 jam pengeringan.

Jelasnya hubungan nilai rata-rata organoleptik rasa ikan layang (Decapterus sp) asin dengan posisi ikan yang berbeda saat dikeringkan dalam alat pengering surya dapat dilihat pada Gambar 4.

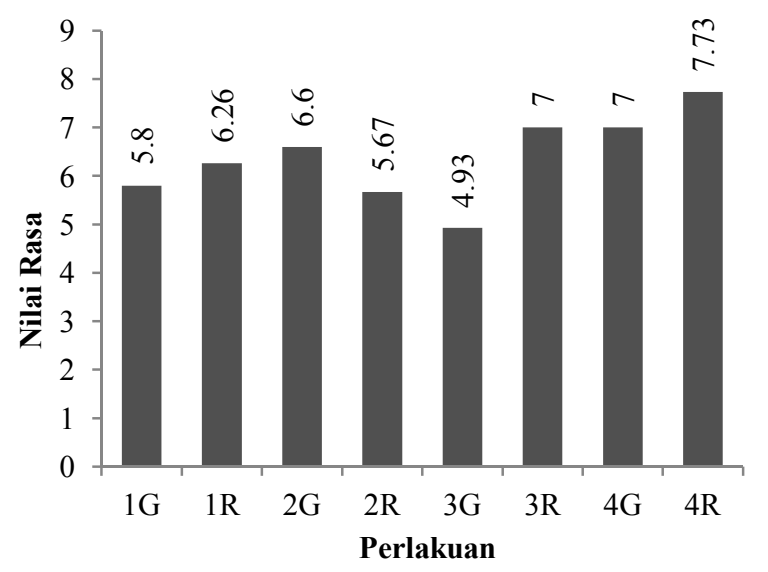

Gambar 4. Hubungan Nilai Organoleptik Rasa ikan Layang (Decapterus sp) asin dengan perlakuan posisi ikan yang berbeda saat dikeringkan.

Berdasarkan Gambar 4 di atas dapat dilihat bahwa pada rak bagian tengah nilai ratarata organoleptik rasa ikan layang asin memiliki nilai yang rendah. Hal ini disebabkan karena bagian tengah dari alat pengering pada saat pengeringan pengaruh suhu semakin berkurang di bandingkan dengan bagian atas dan bagian bawa. Diketahui pula bahwa nilai rata-rata prganoleptik rasa ikan layang asin pada rak bagian bagian bawa memiliki nilai tertinggi dengan posisi ikan di rebahkan selama proses pengeringan berlangsung dalam alat pengering surya

Berdasarkan Standar Nasional Indonesia (1992) nilai organoleptik yang baik adalah 6.5. dengan demikian produk yang mendapat perlakuan pada rak bagian bawa dimana posisi ikan di gantung maupun direbahkan dengan lama pengeringan 8 jam berada pada kisaran mutu yang baik

\section{Konsistensi}

Diketahui nilai rata-rata organoleptik konsistensi yang tertinggi adalah 7.60 yaitu perlakuan pad arak bagoian atas maupun rak 
bagian bawa dengan posisi ikan di gantung dalam alat pengerimng surya selama pengeringan 8 jam, sedangkan nilai rata-rata organoleptik konsistensi terendah adalah 4.67 dengan perlakuan pada rak bagian tengah dengan posisi ikan di gantung dalam alat pengering surya selama pengeringan $8 \mathrm{Jam}$.

Jelasnya hubungan nilai rata-rata organoleptik konsisteensi ikan layang asin dengan perlakuan posisi ikan yang berbeda saat dikeringkan dapat dilihat pada Gambar 5.

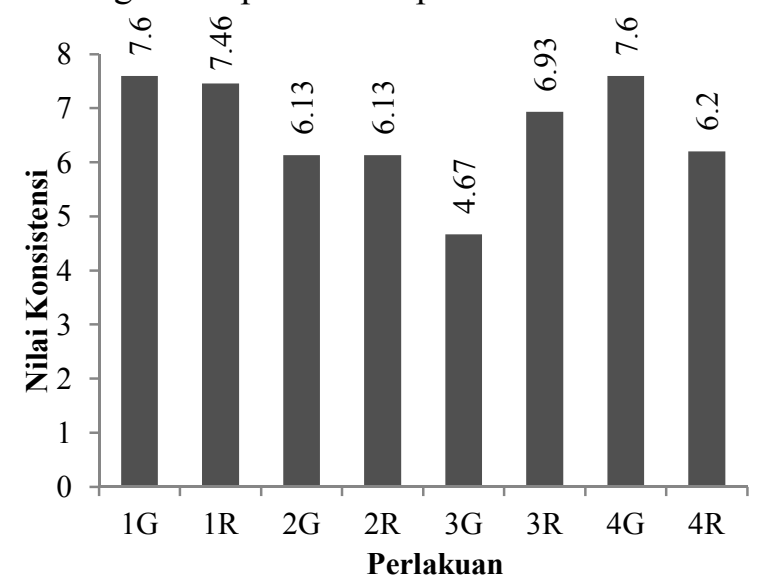

Gambar 5. Hubungan Organoleptik Konsistensi ikan Layang (Decapterus sp) asin dengan perlakuan posisi ikan yang berbeda saat dikeringkan.

Berdasarkan Gambar 5 di atas dapat dilihat bahwa pada rak bagian tengah nilai ratarata organoleptik rasa ikan layang asin memiliki nilai yang rendah. Hal ini disebabkan karena bagian tengah dari alat pengering pada saat pengeringan pengaruh suhu semakin berkurang di bandingkan dengan bagian atas dan bagian bawa. Diketahui pula bahwa nilai rata-rata organoleptik rasa ikan layang asin pada rak bagian bagian bawa memiliki nilai tertinggi dengan posisi ikan di rebahkan selama proses pengeringan berlangsung dalam alat pengering surya.

Berdasarkan Standar Nasional Indonesia (1992) nilai organoleptik yang baik adalah 6.5. Dengan demikian produk yang mendapat perlakuan pad arak bagian atas dengan posisi ikan di gantung dan direbahkan dalam alat pengering surya selama pengeringan 8 jam berada pada kisaran mutu yang baik.

\section{Perubahan Suhu}

Diketahui nilai rata-rata perubahan suhu dalam alat pengering surya yang tertinggi adalah $53^{\circ} \mathrm{C}$ yaitu pada pengamatan jam 14 atau jam 2 siang hari pada rak bagian atas, sedangkan nilai rata -rata perubahan suhu dalam pengering surya terendah adalah $210 \mathrm{C}$ yaitu pada pengamataan jam 17 atau jam 5 sore pada rak bagian bawa.

Untuk jelasnya hubungan waktu pengamatan terhadap perubahan suhu dalam lemari atau alat pengering surya dapat dilihat pada Gambar 6 .

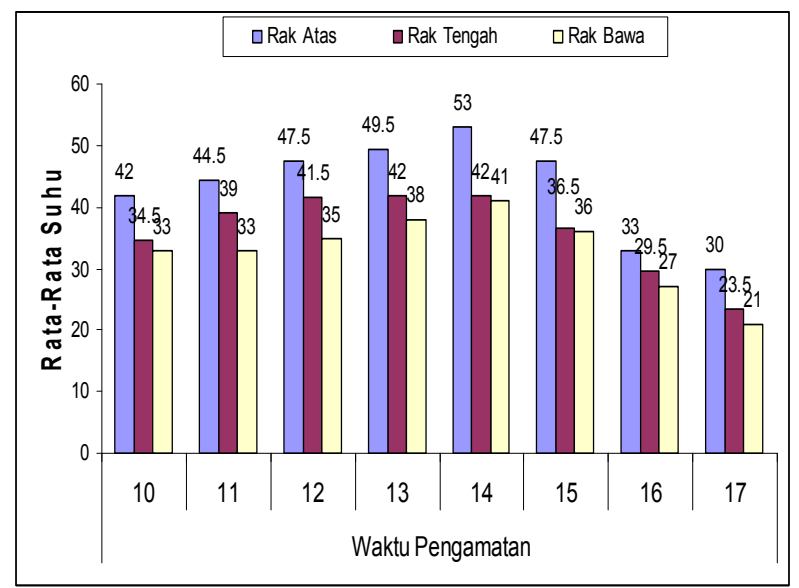

\section{Gambar 6. Hubungan waktu pengamatan terhadap perubahan suhu dalam lemari pengering buatan.}

Berdasarkan Gambar 6 dapat dilihat bahwa suhu dalam alat pengering surya pada pagi hari masih rengah dan meningkat pada siang hari kemudian menurun lagi pada sore hari. Hal ini berhubungan erat erat pengaruh sinar matahari yang menembus bumi dimana pada padi hari suhu lingkungan masih rendah dan siang hari meningkat dan pada sore hari menurun. Keadaan ini memberikan gambaran bahwa suhu lingkungan dalam alat pengering sangat ditentukan oleh jumlah sinar matahari yang menembus alat pengering surya yang di gunakan.

\section{KESIMPULAN}

Berdasarkan hasil penelitian yang telah dilakukan maka dapat disimpulkan beberapa hal yaitu :

- Ikan layang asin yang dikeringkan selama 8 jam dalam alat pengering surya dengan perlakuan pada rak bagian atas dengan posisi ikan di gantung memiliki nilai ratarata kadar air terendah, sedangkan nilai rata -rata organoleptik secara umum pada rak bagian terngah memiliki nilai terendah. 
- Perubahan suhu dalam alat pengering sangat ditentukan oleh suhu lingkungan di luar dalam hal ini pengaruh sinar matahari yang menembus alat pengering surya yang digunakan. Suhu tertinggi pada siang hari yaitu pada jam 14:00 atau jam 2 sore hari.

\section{DAFTAR PUSTAKA}

Afrianio E. dan E. Liviawati. 1989. Pengawetan dan Pengolahan Ikan. Kanisius. Yokyakarta.

Astawan M. 1997. Mengenal Makanan Tradisional Produk Olahan Ikan. http://isjd.pdii.lipi.go.id/admin/jurnal/83975862.pdf. Manado. 15 Februari 2014, Pukul 14.015 Wita.

Berhimpon, S. Souness R. A., Buckle K. A. and Edwards R. A. 1990. The Effect on Brine Concentration on the Salting and Drying of Yellowtail (Trachurus meccullochi). Indo-Pacific Fisheries Camkision (IPFC), FAO-US. FAO Fisheries report No.401 Supplement, pp 153-159.

Badan Standar Nasional. 1992. Standar Nasional Indonesia (SNI) Ikan Asin Kering. Kumpulan Standar Metode Pengujian Mutu Hasil Perikanan. Jakarta.Badan Standar Nasional. 2009. Standar Nasional Indonesia (SNI) lkan Asin Kering. Spesifikasi. Jakarta.

Buckle K. A, R. A Edwards, F. H. Fleet, M. Wooton. 1987. Ilmu Pangan. Penerbit UI - Press. Jakarta. Diterjemahkan oleh Purnomo, H dan Adiono.
Badan Standar Nasional. 2006. Standar Nasional Indonesia (SNI) Cara Uji Kimia. Penentuan Kadar Air Pada Produk Perikanan. Jakarta

Desroisier, N. 1988. Teknologi Pengawetan Bahan Pangan. UI-Press. Jakarta.

Fatabura H. 2012. Metode Penelitian Eksperimen. httpa/sospol.untagsmd.ac.idl?p=347. Manado, 5 Juni 2014, Pukul 14.015 Wita.

Harikedua, J. W., Kaseger B., Sanger G., Setyaningsih L., Singal A., Pandey E., dan Dolonseda S,. 1991. Bahan Ajar Untuk Mata Kuliah Pengantar Pengolahan Hasil Perikanan. Fakultas Perikanan Universitas Sam Ratulangi. Manado.

Margono. T, Suryati, D, Hartinah, S. 2000. lkan Asin Cara Kombinasi Penggaraman dan Peragian (Ikan Peda) httpa/www.warintek. ristek.go.id/pangan kesehatan/pangan/piwp/ikan asin_kombinasi. pdf. Manado, 24 Oktober 2014, Pukul 17.20 Wita

Moeljanto, R. 1982. Penggaraman dan Pengeringan Ikan. Penerbit PT. Penebar Swadaya. Jakarta.

Moeljanto, R. 1992. Pengawetan dan Pengolahan Hasil Perikanan. PT. Penebar Swadaya. Jakarta.

Ruus. O. V. 2009. Pengaruh Konsentrasi Larutan Garam dan Lama Pengeringan Terhadap Mutu lkan Layang (Decapterus sp) Asin Dengan Kadar Garam Rendah. Skripsi. Fakultas Perikanan dan Ilmu Kelautan Universitas Sam Ratutangi. Manado.

Soeseno. 1985. Teknik Penangkapan dan Teknologi Ikan. Yasaguna. Jakarta. 